Article

\title{
Exploring Compliance of AAOIFI Shariah Standard on Ijarah Financing: Analysis on the Practices of Islamic Banks in Malaysia
}

\author{
Shujaat Saleem and Fadillah Mansor * \\ Department of Shariah and Management, University of Malaya, Kuala Lumpur 50603, Malaysia; \\ saleemmshujaat@gmail.com \\ * Correspondence: fadillah@um.edu.my
}

Received: 30 December 2019; Accepted: 13 January 2020; Published: 5 February 2020

check for updates

\begin{abstract}
This paper aims to explore whether the practices of Ijarah financing by Islamic banks in Malaysia are in line with the Accounting and Auditing Organization for Islamic Financial Institutions (AAOIFI) Shariah Standard No: (9) on Ijarah financing. Semi- structured interviews based on open-ended questionnaires were conducted, recorded verbatim, and transcribed for content analysis. Our study revealed flaws in the contemporary practice of Ijarah financing and indicated that it was slightly out of line with the AAOIFI Shariah standard. The study will not only help the Islamic banking industry of Malaysia to reduce, if not eliminate the gap between the practices of Bank Negara Malaysia (BNM) and AAOIFI Shariah standards pertaining to Ijarah financing but also create novel literature due to the fact that, no study has been undertaken to date, which analyzes the practices of Ijarah financing by Malaysian Islamic banks in the light of the AAOIFI Shariah standards.
\end{abstract}

Keywords: Ijarah financing; Malaysian Islamic banks; Islamic finance; AAOIFI standards

\section{Introduction}

According to the teachings of Islam, money is a medium of exchange and should be treated differently from a commodity e.g., a commodity can be sold out or rented out but, money cannot be sold out or rented out ${ }^{1}$ thus, money should be used to buy the commodity and, is not used to buy money (Ahmad and Hassan 2007). Imam Ghazali (May Allah shower His mercy on Him) said nearly 1000 years ago that, the Almighty Allah created money as a medium of exchange. Amongst numerous differences, the main differentiating point between Islamic and conventional banks is the treatment of money and commodities.

Conventional banks treat money equal to commodities on both the deposit and financing side of the transactions as each and every product of a conventional bank is based on a contract of loan which demands fixed interest payments analogous to rent of any asset or property. Conventional banks transfer the entire risk on to the debtor to ensure loan repayment (Cerović et al. 2017). This characteristic of interest based conventional banks can lead to economic disaster and is responsible for the emergence of economic inequality and hence a futile economy. Conversely, Islamic banks treat money as a medium of exchange as no contract of Islamic banks is based on a contract of loan which results in economic activity flourishing and hence economic growth (Maulidizen 2017; 'Usmānī 2002).

1 The meaning of the sentence "Money cannot be sold out or rented out" is that, money cannot be given on loan transaction against any consideration and/or interest. If money is loaned out on interest, it is the same as money is sold out or rented out because in a contract of sale and leasing (renting), consideration is involved. 
Currently, the Islamic banking industry accounts for 71 percent of the overall Islamic financial industry in terms of assets and five hundred and five (505) Islamic banks have presence in sixty nine (69) countries worldwide ${ }^{2}$. Nevertheless, amongst other challenges faced by the Islamic banking industry worldwide, lack of standardization in the legal documentation and Shariah interpretation of the products of Islamic banking also coexist, which becomes one of the main sources to make people not only skeptic and hence opt for conventional interest based financing but also to make investors feel reluctant to invest in Islamic banking products ${ }^{3}$.

Moreover, the literature written against the practices of the Islamic banking industry by the advocates of conventional financé vis-à-vis literature written by its proponents; also tends to create misconception that leads to uncertainty which is difficult for the investor to quantify. On one hand, the proponents of Islamic banking always try to prove that the Islamic banking system is based on a just and fair economic system whereas, the opponents of Islamic banking consider it to be a complete failure and/or mimicry of conventional banking products (Maulidizen 2017).

Due to the inconclusive and indecisive nature of literature about the practices of Ijarah financing by Islamic banks worldwide in general and by Malaysian Islamic banks in particular, there are misconceptions amongst the general public about the Islamic legitimacy on the practices of Ijarah financing by Islamic banks in Malaysia. Therefore the objective of the study is to explore the noncompliance of the AAOIFI Shariah standard on Ijarah financing in the practices of Islamic banks in Malaysia.

Islamic banks in Malaysia are bound to follow BNM Shariah standards in addition to the Shariah standards issued by AAOIFI, therefore numerous studies have been undertaken as to whether or not the practices of Ijarah financing by Islamic banks in Malaysia are in line with the BNM Shariah standard on Ijarah financing. However, no research has been conducted which aims to explore the level of non-compliance in the practices of Ijarah financing by Islamic banks in Malaysia pertaining to the AAOIFI Shariah Standard: 9 on Ijarah financing. Thus, this study seeks to answer the question as to what extent there is a compliance of the AAOIFI Shariah standard on Ijarah financing in the practices of the contemporary Islamic banks of Malaysia. The study helps the Islamic banking industry of Malaysia to reduce, if not eliminate the gap between the practices of BNM and AAOIFI Shariah standards pertaining to Ijarah financing.

An introductory section one (1) of the paper provides an abridged historical background of the Islamic banking industry in Malaysia along with a brief account on the Shariah standard on Ijarah financing issued by both the AAOIFI and BNM. Problem statements and a research gap along with the significance of the study are also included in this section. Whereas, section two (2) presents the detailed account of the literature on Ijarah financing in the perspective of both proponents and opponents' viewpoints. The methodology used in the paper along with the data collection technique and sample size are elaborated in section three (3) of the paper. Moreover, findings are presented in section four (4) which form the basis for the conclusion and recommendation that are presented in section five (5) of the paper.

\subsection{The Historical Background of the Islamic Banking Industry in Malaysia}

Malaysia is considered to be the hub of Islamic banking in the contemporary world where the growth and/or momentum of Islamic financial institutions from Islamic banking and the finance industry to takaful operators, and to Islamic capital markets is highly significant, if measured by any standards (Nor et al. 2016).

Page No: 15-17; Global Islamic Finance Distribution; Islamic Finance Development Report-2018.

Islamic Finance 2019 outlook by S\&P Global Rating, Page No: 4; " Regulatory Reforms and Fintech Are Key Accelerators" by Dr. Mohamed Damak, Senior Director and Global Head of Islamic Finance. 
The essence of Islamic banking in Malaysia was traced back to 1962, when the investment fund was created for the Haj pilgrims by the saving body named, Lembaga Urusan dan Tabung Haji or Haj Pilgrim's Fund Board (Abdullah Saif et al. 2013). The new era of Islamic banking was initiated in the 1980s after the introduction of the Islamic Banking Act, $1983^{4}$ by which, Bank Islam Berhad was incorporated as the first banking company in the country. During this time period, Islamic banking remained in a stage of infancy and was considered to be beneficial only for monolithic Ummah.

During the 1990s, Islamic banking began to expand its roots when amendments in the legislation were made that allowed different conventional banks including Maybank, United Malayan Banking Corporation (UMBC), and Bumiputra Malaysia Berhad (BBMB) to initiate with Islamic banking window operations in the country. In the same era, the Association of Islamic Banking Institutions Malaysia (AIBIM) and the National Shariah Advisory Council were established followed by the inception of the Islamic Interbank Money Market that accelerated the momentum of growth of the Islamic banking industry in the country. This resulted in the formation of Bank Muamlat as the second Islamic bank due to the merger between Bank of Commerce and BBMB (Kunhibava 2012; Nor et al. 2016). Currently, there are sixteen (16) fully-fledged Islamic banks operating in Malaysia as tabulated on the website ${ }^{5}$ of the Shariah Advisory Council of Malaysia.

\subsection{AAOIFI on Ijarah Financing}

In its last meeting held on 11-16 May, 2002 in Madina Al-Munawwarah, the Shariah Board of AAOIFI issued a standard on Ijarah financing with the name of Ijarah and Ijarah Muntahia Bittamleek; Shariah Standard No: 9. The scope of this standard includes (1) Ijrarah tul Aayaan (Ijarah for assets) whether it is a simple Ijarah or Ijarah Muntahia Bittamleek ${ }^{6}$ and whether the Institution is the lessor or lessee. This standard does not encompasses Ijarah tul Ashkhaas (Hiring or service) and Sukuk ul Ijarah as they are covered in separate standards.

Ijarah and Ijarah Muntahia Bittamleek-Shariah Standard No: 9 is divided into eight (8) sections titled; (1) Scope of the standard, (2) Promise to lease an asset, (3) Acquisition of the asset to be leased, or its usufruct, by the institution, (4) Concluding an Ijarah contract and forms of Ijarah, (5) Subject matter of Ijarah, (6) Guarantees and treatment of Ijarah receivables, (7) Changes to the Ijarah contract and, (8) Transfer of ownership in the leased property in Ijarah Muntahia Bittamleek.

\subsection{BNM on Ijarah Financing}

The Shariah standard on Ijarah by BNM was issued on 19 August 2016 which is divided into five parts. Part A, an overview; deals with the introduction, applicability, legal provisions, effective date, and interpretation. Whereas, Part B of the standard presents the Shariah rulings pertaining to components of Ijarah, contracting parties, offer and acceptance, asset and usufruct, rentals, management of Ijarah, arrangement of sub-lease and lease back, forward Ijarah and dissolution and completion of Ijarah contract. Part C and Part D cover operational requirements for Ijarah financing and the operational requirements for the simple Ijarah respectively. Part E of the standard deals with the submission requirement which is followed by four (4) appendices.

Other than Part (A), the clauses under all the parts of the Shariah standard on Ijarah are categorized as either Standard (S), the non-compliance of which is subject to penal action, or Guidance (G) the non-compliance of which is not subject to penal action but contains information, advice and/or recommendation that help Islamic financial institutions in Malaysia for the implementation of sound industry practices.

\footnotetext{
Islamic Banking Act, 1983 has now been repealed by the Islamic Financial Services Act, 2013.

http://www.sacbnm.org/?page_id=3327.

All section of the AAOIFI Shariah Standard No: 9 are applicable to both simple Ijarah and Ijarah Muntahia Bittamleek except section no: 9 which is applicable to only Ijarah Muntahia Bittamleek.
} 


\section{An Overview of Ijarah Financing}

Ijarah is a term in Islamic Fiqh which means to give something on rent. In Ijarah, the usufruct (right to use) of property is transferred to another person for a specified period against agreed consideration called Ujrah (rent). In the Shariah viewpoint, Ijarah is not a contract that transfers ownership in assets to the lessee. Nevertheless, ljarah may be used whereby, in the beginning the lessor enters into the contract of Ijarah with the lessee and in the end, through a separate unconditional contract, ownership in the asset may be transferred to the lessee, the latter is known as Ijarah Muntahia Bittamleek.

The following are some of the options available with the bank to enter into an Ijarah contract with or without signing an agency contract.

(a) The bank owns the asset in advance i.e., the asset is already in the ownership and possession of the bank in which case, the bank may rent it out to the customer on both simple Ijarah and Ijarah Muntahia Bittamleek.

(b) After receiving the customer's request, the bank acquires the ownership of an asset and rents it out to the customer either on simple Ijarah or on Ijarah Muntahia Bittamleek.

(c) The bank acquires the usufruct of an asset on Ijarah Muntahia Bittamleek and rents it out to the customer on Ijarah Muntahia Bittamleek in which case the bank should take into account that, the time period of the first Ijarah should be equal or less than that of the time period of the second ijarah.

(d) The bank acquires the usufruct of an asset on Ijarah Muntahia Bittamleek and rents it out to the customer on simple Ijarah.

(e) The bank gets the usufruct of an asset on simple ijarah and rents it out to the customer on simple ijarah in which case the bank should take into account that, the time period of the first Ijarah is equal to or more than that of the time period of the second Ijarah.

(f) It is not permissible for the bank to get the usufruct of an asset on simple ijarah and rent it out to the customer on Ijarah Muntahia Bittamleek.

\subsection{Opponents' Viewpoint on Ijarah Financing}

(Abozaid 2016) argued that Islamic banks while undertaking Ijarah transactions include the cost of taxes, insurance, and major maintenance in the rentals to be paid by the customer which according to him, is the responsibility of the bank and cannot be included in the Ijarah rentals. Moreover, he posited that, linking rentals with the conventional benchmark e.g., LIBOR leads to gharar kaseer ${ }^{7}$ which makes the transaction impermissible in the eye of Shariah. According to him, some Islamic banks try to convert gharar kaseer into gharar yaseer ${ }^{8}$ but they also seal only one end which benefits the Islamic banks most i.e., the floor. Islamic banks also need to lock the cap to avoid gharar kaseer from the transactions of Ijarah; failing which results in severe divergence from the Maqasid e Shariah.

The findings of (Raza et al. 2011) are similar to that of (Abozaid 2016); they criticized the contemporary Islamic banks by pinpointing the pricing of the Ijarah product that is linked with the conventional benchmark which according to them, leaves no difference between conventional and Islamic banking. Moreover, (Shiyuti et al. 2012) argued that, rentals should not be benchmarked with the interest rates charged by the conventional banks in loan transactions due to the fact that, rentals depict the true consideration for the usufruct of an asset whereas, interest rate has no link with the usufruct of the asset.

In his work titled, "Use of Hiyal in Islamic Finance and its Shariah Legitimacy" (Mansoori 2011) argued that, current practices of Islamic banks are discounting the principles of Shariah to become

7 Major uncertainty within the clauses of transactions that leads to dispute.

8 Minor uncertainty within the clauses of transaction that does not lead to dispute. 
profitable by using Hiyal (tricky solutions and clever uses of law to achieve a legitimate end), especially in Ijarah transactions. Moreover, Islamic banks have been violating the true spirit of Islamic economics and finance since 1984 by using Hiyal in its transactions, however the proportion of Hiyal in the transactions of Islamic banks has been reduced since then and has been replaced by Makharij (wise answers to difficult problems). These are in fact, the cleaver usage of law to achieve a legitimate end, that harms the overall objectives of the Islamic economic system (Mansoori 2011).

The findings of (Dusuki and Abozaid 2007) are somewhat similar to that of the findings of (Mansoori 2011). (Dusuki and Abozaid 2007) found that, transactions of Islamic banks are different in their form but have the same substance as of impermissible transactions of interest based conventional banks and hence, impermissible in the eye of Shariah. Similarly, (El-Gamal 2006) criticized contemporary Islamic banks by using the terminology 'Shariah Arbitrage'.

\subsection{Proponents' Viewpoint on Ijarah Financing}

(Ahmad 2013) in his study seems to be discontent with the finding of (Abozaid 2016) and (Raza et al. 2011). He delineated that, interest is prohibited according to the teachings of Islam but it is permissible to create debt through loan transaction without interest and it is also permissible to claim rent in an Ijarah transaction as the same is permissible in accordance with Islamic jurisprudence.

On the issue of benchmarking Ijarah rentals with interest rates (Lewis 2008) delineated that, the majority of Islamic scholars are of the point of view that, it is permissible to link ljarah rentals with interest rates provided that a floor and cap are imposed as the lower and upper limits respectively, and the first period rentals must be fixed at the time of signing the Ijarah contract.

Regarding rentals in an Ijarah transaction, (Ahmad and Hassan 2006) found that, in accordance with the opinion of the majority of Islamic scholars; it is impermissible to index indebtedness with inflation rates due to the fact that the purpose of a loan transaction in Islamic Shariah is to serve humanity and to seek the pleasure of Almighty Allah. However according to them, it is permissible to include the expected rate of inflation in determining ljarah rentals in the contract of Ijarah.

The findings of (Nagaoka 2012) are different from that of (Dusuki and Abozaid 2007), while describing the complete process flow of Ijarah financing; he seems to have contention with the permissibility of Ijarah financing being undertaken by the contemporary Islamic banks. According to him, the unique structure of Ijarah financing makes it a better alternative to conventional finance lease, as Ijarah financing is the contract which involves trade.

In his study about the legality of Islamic banking products, (Lewis 2008) concluded that, Ijarah financing is permissible in Islam and no School of Islamic Thought raises the question on the permissibility of Ijarah financing. He found that, most of the renowned Islamic scholars are trying to replicate the products of Islamic banks with conventional interest based transactions which makes it difficult for a common man to understand the differences between conventional and Islamic banking.

\section{Methodology and Data Collection}

This study is qualitative, descriptive as well as exploratory in its nature and uses survey strategy. We formulated an open ended questionnaire for Ijarah financing from the AAOIFI Shariah standard: 9 on Ijarah financing to be used for conducting semi-structured interviews that were transcribed for content analysis. Open-ended questions were formulated taking into account the extensive review of literature along with the experts' opinion from the Islamic banking practitioners in Malaysia. Thus, the study is descriptive as according to (Saunders et al. 2009), in descriptive studies, before the collection of data, the researcher possesses an idea about the problem for which data is to be collected. Furthermore, a study of this kind has never been undertaken before, thus the study is exploratory as well.

As the main intent of the study is to explore as to whether or not the practices of Ijarah financing of the contemporary Islamic banks in Malaysia are in compliance with the AAOIFI Shariah Standard:9 on Ijarah financing, therefore the study adopts a qualitative approach with semi- structured interviews using open-ended questions by applying an inductive approach. According to (Creswell et al. 2003) 
an inductive approach is applied when the title of the study is exciting and entails much debate. Moreover, survey strategy is known for collecting data through questionnaires which gather data by conducting semi-structured interviews through a standard questionnaire that asks the same questions from interviewees (Saunders et al. 2009). Since to accomplish the objectives of this study, we gathered data from a standard questionnaire that asked the same questions from all the interviewees, the study thus uses survey strategy.

The population of the study comprise all the Shariah committee members and bank managers of the Malaysian Islamic banks. The sample size of the study is ten (10) interviewees i.e., it comprises two (2) personnel and/or respondents amongst all the Shariah committee members and bank managers of the Islamic banks in Kuala Lumpur, Malaysia tabulated below in Table 1. As Kuala Lumpur is the financial capital of the country, the results may thus be generalized across Malaysia.

Table 1. Sampled Islamic Banks in Malaysia.

\begin{tabular}{c}
\hline Names \\
\hline Affin Islamic Bank Berhad \\
MUFG Bank (Malaysia) Berhad \\
CIMB Islamic Bank Berhad \\
Bank Muamalat Malaysia Berhad \\
HSBC Amanah
\end{tabular}

Note: This table is constructed after taking into account the website http://www.bnm.gov.my/?ch=li\&cat=islamic\& type $=$ IB\&lang $=$ en .

The rationale to choose the aforementioned respondents is that, members of Shariah committee and bank managers do not only possess the complete knowledge and understanding about the products but are also well versed on its implementation by the Islamic banks.

The rationale for interviewing two interviewees from each Islamic bank is twofold, (1) if one of the interviewees lacks knowledge or is unable to give a response to any question, then the other interviewee may fill the gap, (2) the response given by one interviewee about the contemporary practice of Islamic bank can be verified by another interviewee from the same Islamic bank.

The rationale of not interviewing more than two (2) interviewees from the same Islamic bank is that, in our opinion, research questions were answered and research objectives were accomplished after taking two (2) responses from the same Islamic bank i.e., conducting one or more interviewees results in data becoming oversaturated.

In order to validate the analysis through semi-structured interviews, secondary data were also gathered from the product disclosure sheets and from the AAOIFI Shariah standard on Ijarah financing. A similar data collection method was used by (Shafiq 2012) in his study titled, "De-secularizing finance: Islamic banking in Pakistan".

\section{Findings}

In order to explore the compliance in the practices of Malaysian Islamic banks pertaining to the AAOIFI Shariah standard on Ijarah financing, we used an open-ended questionnaire which was utilized to conduct semi-structured interviews from the respondents of Islamic banks in Malaysia. We made a transcript of fifty two (52) pages by conducting ten (10) open-ended interviews from the members of the Shariah committee and bank managers of the five (5) Islamic banks in Malaysia, the details of which were presented in the previous section on methodology.

Moreover, interview contents were used to generate codes of the respective clauses of noncompliance that enabled the researchers develop a theme for the same ones. Through content analysis, we have explored the following (from Sections 4.1-4.4) issues in the practices of contemporary Islamic banks in Malaysia which are not in line with the AAOIFI Shariah Standard No: 9 on Ijarah financing.

While conducting the interviews, researchers did not probe the reasons for non-compliance of the AAOIFI Shariah standard on Ijarah financing due to the fact that, it is outside the purview of 
the research objectives set for this thesis, as to follow AAOIFI Shariah standards is not obligatory for the Islamic banks in Malaysia, rather Malaysian Islamic banks are legally bound to comply with the Shariah standards issued by BNM.

\subsection{Clause 3/7-Agency}

According to the AAOIFI Shariah standard on Ijarah financing, it is preferred that the agency contract be made not with the prospective customer, rather a third party is appointed as the bank's agent as presented in the following clause: $3 / 7$

"It is always preferred that the agent is someone other than the customer (prospective lessee) as far as possible"

When asked from the interviewees, "Does your bank appoint a customer as its agent in acquiring the asset?, it was determined from the responses that Islamic banks in Malaysia sign the agency contract with prospective customers in all Ijarah transactions without taking into account whether or not there is a dire need of becoming the prospective customer as an agent of the bank. Hence, Islamic banks in Malaysia are found to observe a moderate level of non-compliance of the aforementioned clause: 3/7 of the AAOIFI Shariah standard on Ijarah financing. One of the respondents said,

"Actually from legal perspective we provide appendix in which agency agreement is there"

Although not disclosed by any respondent, it was also determined by the researchers that Islamic banks enter into an agency contract with the customer in each and every ljarah transaction due to the fact that the same is allowed by BNM in its Shariah standard on Ijarah financing.

From the detailed account of transcribed interviews conducted from the ten (10) interviewees, ten (10) codes were generated. Moreover, after taking into account all the codes, the researchers developed the theme in regard to non-compliance of the clause 3/7, as depicted in the following Table 2.

Table 2. Clause: 3/7-Agency.

\begin{tabular}{|c|c|c|}
\hline $\begin{array}{c}\text { Clause in Which } \\
\text { Non-Compliance Is Explored }\end{array}$ & Codes from Interviewee's Responses & Theme \\
\hline \multirow{11}{*}{ Clause No 3/7 Agency } & Interviews from 10 respondents based on 10 codes & \multirow{11}{*}{$\begin{array}{l}\text { Customer acts as } \\
\text { agent of the } \\
\text { bank in all Ijarah } \\
\text { transactions }\end{array}$} \\
\hline & Yes in most of the time & \\
\hline & Yes, we enters into agency agreement with the customer & \\
\hline & $\begin{array}{l}\text { Actually from legal perspective we provide an appendix } \\
\text { in which the agency agreement is there }\end{array}$ & \\
\hline & Yes & \\
\hline & Yes & \\
\hline & Yes & \\
\hline & Yes & \\
\hline & Yes & \\
\hline & Yes & \\
\hline & Yes & \\
\hline
\end{tabular}

Note: This table is developed with the help of qualitative content analysis of the transcribed interviews pertaining to clause: $3 / 7$ of the Shariah Standard No: 9 on Ijarah financing.

In order to verify the analysis done through primary data, secondary data from the BNM Shariah standard on Ijarah financing was analyzed and it was found that the secondary data validates the findings obtained through the primary data. The following section: 13.4 of the BNM Shariah standard on Ijarah financing permits Malaysian Islamic banks to enter into a contract of agency with the prospective customer. 
"The lessor may appoint the lessee or a third party as an agent to acquire the asset to be leased"

\subsection{Clause No: 5/1/8-Takaful}

In order to execute ljarah transactions, it is not necessary for the Islamic banks to take insurance cover unless it is made compulsory by the regulatory authorities. However, if Islamic banks take insurance cover then it must be from permissible sources i.e., Islamic banks should obtain insurance cover from takaful operators as mentioned in the following clause: 5/1/8 of the AAOIFI Shariah standard on Ijarah financing.

"The lessor may take out permissible insurance on it whenever possible and may also delegate to the

lessee the task of taking out insurance at the lessor's expense"

While conducting the interviews, it was found that Islamic banks in Malaysia delegate the responsibility of taking insurance cover to the customer and it is allowed for a customer to take insurance cover from both a conventional as well as an Islamic insurance company which is a sheer violation of the aforementioned clause of the AAOIFI Shariah standard on Ijarah financing. One of the interviewees responded in the following words.

"If takaful is not available only then we go for the conventional insurance"

Almost all the respondents were of the point of view that, Islamic banks in Malaysia always prefer takaful operators over conventional insurance. However, in the case of need, conventional insurance may also be obtained e.g., when the customer's application for taking insurance cover is rejected by the takaful operator or when the risk exposure is too high to be covered by the takaful operator.

Table 3 presents the codes generated from the detailed transcribed interviews of all the interviewees pertaining to clause: 5/1/8. From the detailed account of the transcribed interviews conducted from the ten (10) interviewees, ten (10) codes were generated. Moreover, after taking into account all the codes, the researchers developed the theme with regard to non-compliance of the clause: 5/1/8 of the AAOIFI Shariah Standard which is presented in Table 3.

Table 3. Clause: 5/1/8-Takaful.

\begin{tabular}{|c|c|c|}
\hline $\begin{array}{l}\text { Clause in Which } \\
\text { Non-Compliance Is Explored }\end{array}$ & Codes from Interviewee's Responses & Theme \\
\hline \multirow{11}{*}{ Clause No 5/1/8 Takaful } & Interviews from 10 respondents based on 10 codes & \multirow{11}{*}{$\begin{array}{c}\text { Islamic banks in } \\
\text { Malaysia obtain } \\
\text { insurance cover from } \\
\text { both the takaful operators } \\
\text { and conventional } \\
\text { insurance companies }\end{array}$} \\
\hline & $\begin{array}{l}100 \text { percent takaful except in those cases where the client has } \\
\text { got a panel }\end{array}$ & \\
\hline & $\begin{array}{l}\text { if takaful is not available only then we go for the } \\
\text { conventional insurance }\end{array}$ & \\
\hline & I cannot say whether it is $100 \%$ or not & \\
\hline & $\begin{array}{c}\text { in case of need conventional insurance is used to take } \\
\text { insurance cover }\end{array}$ & \\
\hline & sometimes conventional insurance & \\
\hline & customer's application is rejected by takaful operator & \\
\hline & $\begin{array}{l}\text { Mostly takaful but the bank takes conventional insurance } \\
\text { cover too }\end{array}$ & \\
\hline & $\begin{array}{l}\text { sometimes when the amount is too high then a customer can } \\
\text { go for conventional insurance }\end{array}$ & \\
\hline & in minimal transactions conventional insurance is also taken & \\
\hline & Both takaful and conventional insurance are practiced & \\
\hline
\end{tabular}

Note: This table is developed with the help of qualitative content analysis of the transcribed interviews pertaining to clause: $5 / 1 / 8$ of the Shariah Standard No: 9 on Ijarah financing.

After having analyzed the secondary data, it was found that secondary data validates the finding obtained through primary data as the Shariah Advisory Council (SAC) of the Bank Negara Malaysia 
in its 47th meeting dated 14 February 2005 passed its resolution which permits subscribing with conventional insurance on the following conditions.

(a) First preference shall be given to takaful or re-takaful companies.

(b) When a takaful or re-takaful company does not exist which can absorb the entire risk.

(c) When there is a doubt on the strength of the takaful or re-takaful company.

It was determined that in principle, it is mandatory to obtain insurance cover from takaful operators as mentioned in the following section: 16.7 of the BNM Shariah standard on Ijarah financing but in case of need, obtaining insurance cover from conventional insurance companies is also allowed by the SAC of the Bank Negara Malaysia.

Section: 16.7 of the BNM on Ijarah financing is as follows:

"The lessor may mitigate specific risks relating to loss, damage or impairment of the leased asset through a takaful coverage" and

\subsection{Clauses 6/3 and 6/4-Late Payment Penalty}

According to the clauses $6 / 3$ and $6 / 4$ of the AAOIFI Shariah standard on Ijarah financing, Islamic banks cannot charge an additional amount in case of delay of payment of rentals by the customer, however if the delay is not due to a good reason acceptable to Shariah i.e., instead of capability to pay the rentals if the customer is not paying, then according to the contract, the customer pays a certain amount to charity as undertaken by him while signing the contract of Ijarah.

By analyzing the clauses: $6 / 3$ and 6/4, it is revealed that if the customer is not paying the rentals without any good reason acceptable to Shariah then he shall pay a certain amount to charitable organizations i.e., the amount received by the bank cannot become part of the bank's income.

Nevertheless, while conducting the interviews it was determined that all the Islamic banks in Malaysia charge a late payment penalty in the name of ta'widh (compensation) which becomes the bank's income, unlike gharamah (penalty) i.e., gharamah cannot become a part of the bank's income. One of the interviewees said,

"We charge $1 \%$ as actual cost as ta'widh. It's not more than $1 \%$. This is $1 \%$ of the outstanding amount"

The other interviewee responded in the following words,

"We charge ta'widh and gharamah as we charge in Murabaha"

After having conducted the interviews, it was found that in case of delay of payment of rentals by the solvent customer, Islamic banks charge ta'widh instead of gharamah as the same cannot become part of the bank's income. Ten (10) codes from the rigorous and detailed analysis of the ten (10) transcribed interviews were developed and are tabulated as follows in Table 4.

When the researchers analyzed the secondary documents i.e., BNM Shariah standard on Ijarah financing along with the product disclosure sheets of Islamic banks in Malaysia, it was found that the secondary data conforms with the findings obtained through primary data. The clauses from 26.1 to 26.4 of the BNM Shariah standard on Ijarah financing permit Islamic banks to charge ta'widh which becomes the income of the bank, nevertheless the amount of gharamah shall be given to charity. Furthermore, the undermentioned section: 6 of the product disclosure sheet of the Affin Islamic Bank asks customers to pay ta'widh.

"Customer shall pay the bank late payment charges by way of Ta'widh" 
Table 4. Clause: 6/3 and 6/4-Late Payment Penalty.

\begin{tabular}{|c|c|c|}
\hline $\begin{array}{l}\text { Clause in Which } \\
\text { Non-Compliance Is Explored }\end{array}$ & Codes from Interviewee's Responses & Theme \\
\hline \multirow{11}{*}{$\begin{array}{l}\text { Clauses: } 6 / 3 \text { and } 6 / 4 \text { Late } \\
\text { Payment Penalty }\end{array}$} & $\begin{array}{l}\text { Interviews from } 10 \text { respondents based on } 10 \\
\text { codes }\end{array}$ & \multirow{11}{*}{$\begin{array}{l}\text { Islamic banks charge } \\
\text { the customer with } \\
\text { ta'widh and gharamah }\end{array}$} \\
\hline & $\begin{array}{l}\text { Ta'widh and gharamah as we charge in the case } \\
\text { of Murabaha financing }\end{array}$ & \\
\hline & Ta'wid is charged, yes & \\
\hline & Yes ta'wid and gharamah & \\
\hline & Yes it does & \\
\hline & $\begin{array}{l}\text { We charge } 1 \text { percent as actual cost in the name of } \\
\text { ta'wid. It's not more than } 1 \text { percent. This } 1 \\
\text { percent of the outstanding amount }\end{array}$ & \\
\hline & Similar to what we charge in Murabaha financing & \\
\hline & Yes, ta'wid & \\
\hline & Yes & \\
\hline & Yes & \\
\hline & Yes & \\
\hline
\end{tabular}

Note: This table is developed with the help of qualitative content analysis of the transcribed interviews pertaining to clauses: 6/3 and 6/4 of the AAOIFI Shariah Standard No: 9 on Ijarah financing.

\subsection{Clause 8/5-Sale and Lease Back}

In order to avoid contract of inah, clause $8 / 5$ of the AAOIFI Shariah standard makes it compulsory that a considerable period of time lapses in between the two contracts of sale and lease back. i.e., when the asset is purchased by one party and leased back to the same party on the basis of Ijarah Muntahia Bittamleek, it is necessary that a reasonable time in between the sale and lease back transactions must have expired during which either the asset or its value may have changed as stated in the clause $8 / 5$ of the AAOIFI Shariah standard: 9 on Ijarah financing.

When the researchers explored the implementation of the aforementioned clause in the practice of the Islamic banking industry of Malaysia, it was determined that Islamic banks in Malaysia execute both the transactions of sale and lease back instantly without giving any considerable time in between the two contracts. One of the respondents uttered the following in this regard,

"This is in one sitting. First we buy and then lease out"

The other interviewee briefly answered in the following words.

"Almost instantaneous"

After the rigorous analysis of the ten (10) transcribed interviews, the researchers generated ten (10) codes from which a theme was developed and is presented in the Table 5 as follows. 
Table 5. Clause: 8/5—Sale and Lease Back.

\begin{tabular}{|c|c|c|}
\hline $\begin{array}{l}\text { Clause in which } \\
\text { Non-Compliance Is Explored }\end{array}$ & Codes from Interviewee's Responses & Theme \\
\hline \multirow{11}{*}{ Clauses: $8 / 5$ Sale and Lease Back } & Interviews from 10 respondents based on 10 codes & \multirow{11}{*}{$\begin{array}{l}\text { Sale and lease back } \\
\text { transactions are } \\
\text { executed instantly }\end{array}$} \\
\hline & Instant & \\
\hline & It's very quick in Malaysia & \\
\hline & No time is specific & \\
\hline & Yes it does & \\
\hline & This is in one sitting. First we buy and then leased out & \\
\hline & In one meeting & \\
\hline & Almost instantaneous & \\
\hline & There is no specific time & \\
\hline & $\begin{array}{l}\text { We don't take into account the particular time period; it } \\
\text { may be done in one go }\end{array}$ & \\
\hline & Yes & \\
\hline
\end{tabular}

Note: This table is developed with the help of qualitative content analysis of the transcribed interviews pertaining to clauses $8 / 5$ of the AAOIFI Shariah Standard No: 9 on Ijarah financing.

\subsection{Summary}

After the detailed and rigorous analysis of all the transcribed interviews along with the analysis of secondary data obtained from contractual documents of all the full-fledged Islamic banks in Malaysia, Islamic banks were found to observe non-compliance of the four (4) clauses due to reasons elaborated in Section 4.

The following Table 6 summarizes Section 4 in terms of generating codes and developing themes pertaining to non-compliance ${ }^{9}$ of the four (4) clauses of the AAOIFI Shariah Standard No: 9 on Ijarah financing by Islamic banks in Malaysia.

Table 6. Non-Compliance of AAOIFI Shariah Standard No: 9 by Islamic Banks in Malaysia.

\begin{tabular}{ccc}
\hline \multicolumn{1}{c}{ Themes } & Number of Interviewees & Number of Codes \\
\hline $\begin{array}{c}\text { Customer acts as agent of the bank in all Ijarah transactions } \\
\text { Moderate level of non-compliance of the clause } 3 / 7\end{array}$ & 10 & 10 \\
\hline $\begin{array}{c}\text { Islamic banks in Malaysia obtain insurance cover from both the } \\
\text { takaful operators and conventional insurance companies } \\
\text { High level of non-compliance of the clause 5/1/8 }\end{array}$ & 10 & 10 \\
\hline $\begin{array}{c}\text { Islamic banks charge the customer with Ta'widh and Gharamah } \\
\text { High level of non-compliance of the } \mathbf{6 / 3} \text { and } \mathbf{6 / 4}\end{array}$ & 10 & 10 \\
\hline $\begin{array}{c}\text { Sale and lease back transactions are executed instantly } \\
\text { High level of non-compliance of the clause 8/5 }\end{array}$ & 10 & 10 \\
\hline
\end{tabular}

Note: This table is developed with the help of Tables $2-5$ of the previous Section 4.

9 After taking into account the experts' opinion, the researchers divided the extent of non-compliance into two categories (1) high level of non-compliance and (2) moderate level of non-compliance.

(1) High level of non-compliance was analyzed and presented when it was found that the practices of Islamic banks deviated from such clauses, the practice and/or implementation of which is considered as mandatory by the AAOIFI Shariah Standard:9 on Ijarah financing by using the words; must or obligatory.

(2) Moderate level of non-compliance was analyzed and presented when it was found that the practices of Islamic banks deviated from such clauses, the practice and/or implementation of which is not considered as mandatory by the AAOIFI Shariah Standard: 9 on Ijarah financing by using the words; preferable or may not need. 


\section{Conclusions and Recommendations}

The study provides evidences of the non-compliance of the AAOIFI four (4) clauses of the Shariah standard No: 9 by Islamic banks in Malaysia, our recommendations to the competent authorities are as follows:

(a) In order to make the practices of Malaysian Islamic banks have compliance with the clause 3/7 (agency) of the AAOIFI Shariah Standard No: 9 on Ijarah financing, it is recommended that the Government of Malaysia along with the Bank Negara Malaysia establish Islamic Trading Houses which are legally authorized to directly purchase goods from the supplier identified by the customer and store the same goods in the warehouse.

(b) Until the establishment of Islamic Trading Houses in Malaysia, Bank Negara Malaysia is recommended to develop such polices through which each and every Islamic bank may directly purchase goods from the supplier identified by the customer and store the same goods in its warehouses.

(c) It is recommended to frame and implement such policies which not only augment the proportion of takaful operators in Malaysia compared to conventional insurance companies but also enhance the risk exposure limit of takaful operators so that Islamic banks in Malaysia would not obtain insurance cover from conventional insurance companies.

(d) To make harmony between and within different Shariah standards issued by AAOIFI and BNM in general, and on the Shariah standard on Ijarah financing in particular, it is recommended not to charge ta'widh from the customer as the purpose of charging ta'widh may also be achieved through gharamah.

(e) The BNM is proposed to develop such policies that restrict Malaysian Islamic commercial banks of instant execution of the sale and lease back contract to avoid bai-inah, as recommended by AAOIFI.

Author Contributions: Both authors are participated in this research as the first author is the main investigator and the corresponding author is his supervisor. This research is partially based on UM research projects, RP008D-13SBS and GPF007L-2018.The first author initiated the original manuscript, and then the revised draft and its changes was incorporated by the corresponding author. All authors have read and agreed to the published version of the manuscript.

Funding: This research received no external funding.

Conflicts of Interest: The authors declare no conflict of interest.

\section{References}

Abdullah Saif, Al Nasser, Sulaiman Datin, and Joriah Muhammed. 2013. Introduction to history of Islamic banking in Malaysia. Humanomics 29: 80-87. [CrossRef]

Abozaid, Abdulazeem. 2016. The internal challenges facing Islamic finance industry. International Journal of Islamic and Middle Eastern Finance and Management 9: 222-35. [CrossRef]

Ahmad, Abu Umar Faruq, and M. Kabir Hassan. 2006. The time value of money concept in Islamic finance. American Journal of Islamic Social Sciences 23: 66. [CrossRef]

Ahmad, Abu Umar Faruq, and M. Kabir Hassan. 2007. Riba and Islamic banking. Journal of Islamic Economics, Banking and Finance 3: 1-33.

Ahmad, Syed Zahid. 2013. Why Murabaha (Cost-plus Finance) Is Allowed Whereas Lending on Interest Is Prohibited in Islam? Journal of Islamic Banking and Finance 30: 19-23.

Cerović, Ljerka, Stella Suljić Nikolaj MEcon, and Maradin Dario. 2017. Comparative analysis of conventional and Islamic banking: Importance of market regulation 1. Ekonomska Misao i Praksa 26: 241.

Creswell, John W., Vickie L. Plano Clark, Michelle L. Gutmann, and William E. Hanson. 2003. Advanced mixed methods research designs. In Handbook of Mixed Methods in Social and Behavioral Research. Thousand Oaks: Sage, pp. 209-40.

Dusuki, Asyraf Wajdi, and Abdulazeem Abozaid. 2007. A critical appraisal on the challenges of realizing Maqasid al-Shariah in Islamic banking and finance. IIUM Journal of Economics and Management 15: 143-65. 
El-Gamal, Mahmoud A. 2006. Islamic Finance: Law, Economics, and Practice. Cambridge: Cambridge University Press. Kunhibava, Sherin. 2012. Islamic Banking in Malaysia. International Journal of Legal Information 40: 191-201. [CrossRef]

Lewis, Mervyn K. 2008. In what ways does Islamic banking differ from conventional finance. Journal of Islamic Economics, Banking and Finance (JIEBF) 4: 9-24.

Mansoori, Muhammad Tahir. 2011. Use of Hiyal in Islamic Finance and its Sharīah Legitimacy. Journal of Islamic Business and Management 1: 69-92.

Maulidizen, Ahmad. 2017. Islamic Finance in Theory and Practice a Critical Analysis. Islamiconomic: Jurnal Ekonomi Islam 8: 111-40. [CrossRef]

Nagaoka, Shinsuke. 2012. Critical overview of the history of Islamic economics: Formation, transformation, and new horizons. Asian and African Area Studies 11: 114-36.

Nor, Mohd Zakhiri, Mohd Zakhiri, Ani Munirah Mohamad, and Hakimah Yaacob. 2016. The Development of Islamic Finance in Malaysia. In Islamic Banking and Finance: Principles, Instruments \& Operations, 2nd ed. Edited by Adnan Trakic and Hanifah Haydar Ali Tajuddin. Selangor: CLJ Publication, pp. 601-17.

Raza, Muhammad Wajid, Syed Farhan Shah, and Malik Rizwan Khurshid. 2011. Islamic Banking Controversies and Challenges. Munich: University Library of Munich.

Saunders, Mark, Philip Lewis, Adrian Thornhill, and Jonathan Wilson. 2009. Business Research Methods. London: Financial Times, Prentice Hall.

Shafiq, Sarah. 2012. De-Secularizing Finance: Islamic Banking in Pakistan. Ph.D. Thesis, University of Notre Dame, Notre Dame, Indiana; p. 139.

Shiyuti, Hashim Ahmad, Delil Khairat, Mahamat Mourtada, and Muhammad Ghani. 2012. Critical Evaluation on Al-Ijarah Thummalbai' (August 3, 2012). Asian Finance Association (AsFA) 2013 Conference. Available online: https://ssrn.com/abstract=2184296orhttp://dx.doi.org/10.2139/ssrn.2184296 (accessed on 20 December 2019).

‘Usmān̄ī, Muhammad Taqī. 2002. An Introduction to Islamic Finance. Highwood: Brill, vol. 20.

(C) 2020 by the authors. Licensee MDPI, Basel, Switzerland. This article is an open access article distributed under the terms and conditions of the Creative Commons Attribution (CC BY) license (http://creativecommons.org/licenses/by/4.0/). 